Breeding from the Cambridge Botany School alone. Other botany depariments continue to make similar contributions at all grades to the research staffs of institutes and teaching organizations throughout agriculture, horticulture, forestry and fishories. It is not that botany is dead, but that the grossest ignorance prevails in the general public and even in scientific circles of what modern botany is like and what its achievements have been. Nor, of course, is it appreciated how greatly the subject has been modernized or the extent to which, both in teaching and research, botany courses regularly involve the most sophisticated physicochemical and mathematical techniques. This can be appreciated only by visiting laboratories and lecture rooms to see modern courses in full swing (and few opinions are bascd on such visits), but it can also easily be seen by examining the leading journals of botany, such as the American Journal of Botany, the New Phytologist or the Annals of Botany. It is at once apparent that most of their papcrs have a strongly experimental and quantitative approach and reflect the manner in which botanists today have adopted physicochemical and mathematical techniques, and clearly base their approach on discovery and evaluation of the causative mechanisms and processes involved in plant life.

The old mainspring of the subject, the elucidation of conjectural evolutionary origins by comparative studies of anatomy and life histories is now taught at more reasonable length, and in every arca of research, even including taxonomy, modern experimental methods are making strong headway. Furthermore, although botanical journals reflect the fact that botanists are sharing in the advances of molecular biology at the biochemical and biophysical level, there is a large and growing interest in the biology of the whole organism, and of the whole organism in relation to its environment. 'The importance of this approach for the applied biological sciences, such as agriculture, horticulture, forestry and fisheries, needs little emphasis, but the realization of it is shown by such things as the successful inauguration of the new Journal of Applied Ecology, following the Journal of Animal Ecology and the Journal of Ecology by the British Ecological Society. It is oqually apparent throughout the whole of the current International Biological Programme.

So long as one believes that the study of the whole organism is bound to have an increasing role in the future, one is committed, I belicve, to the maintenance of the long established departments of botany and zoology, where the integration of many fields of research has long taken place around the wholo plant and the whole organism. There are such tremendous repositories of important scientific information within the areas of these two old established subjects that there would be irretrievable loss in merging them into new schools of biology exploiting for the moment nothing but the most fashionable new approaches. It is impossible to forecast where in animal or plant biology the next breakthrough will oceur and from what branch of inquiry, probably long dormant, growth will be stimulated by some new technique, new evidenes or new mode of thought. Without the maintenance of the libraries, museums and, above all, the synthesizing courses centred on the whole plant or the whole animal, it would be difficult, if not impossible, for these now advances to arise, nor without an approach of this breadth will new generations be given awareness of the whole biological environment in relation to the life of man.

$$
\text { Yours fuithfully, }
$$

H. GoDwIN

Botany School, Cambridge.

This letter refors to two articles in the November 9 issue of Nature, one on page 521 and one on page 541.--Editor, Nature.

\section{Monod at Edinburgh}

Sir,--Your correspondent, reporting on Professor Monod's address at Edinburgh in your issue of November 23 (Nature, 220, 744; 1968), produces, or repeats, a misquotation when he refers to my old definition of molecular biology as follows: "quoting Chargaff's "chemistry without a licence'-..". Lost this inferior version gain currency, may I quote what the "Old Chemist" really said in the dialogue Amphisbaena (Essays on Nucleic Acids, p. 176): "My definition, incidentally, would be that molecular biology is essentially the practice of biochemistry without a licence.".

\section{Yours faithfully,}

('olumbia University,

Erwin Chargafe

New York, NY, 10032.

\section{University News}

Dr F. Glockling has bcen appointed to the chair of inorganic chemistry at the Queen's University of Belfast.

Dr P. L. Marsden has been awarded a personal professorship in the Department of Physics at the University of Leeds.

Professor L. Brent, Southampton, has been appointed to the Pfizor chair of immunology tenable at St Mary's Hospital Medical School, London.

\section{Appointments}

Mr W. A. Cumming has been appointed director of the Radio and Electrical Fngineering Division of the National Research Council of Canada. Dr A. E. Douglas has been appointed director of the council's Division of Applied Physics.

\section{Announcements}

The following medals have been awarded by the Royal Society : the Copley Medal to Professor T. Reichstein, formerly of the University of Basle, for his work on the chemistry of vitamin $\mathrm{C}$ and his studies of the corticosteroids; the Rumford Medal to Professor D. Gabor, Imperial College of Science and Technology and CBS Laboratories, Stanford, for his contributions to optics, especially by establishing the principles of holography : the Davy Medal to Dr J. W. Cornforth, Milstead Laboratory of Chemical Enzymology, and to Professor J. G. Popják, University of California, for their work on the elucidation of the biosynthetic pathway to polyisoprenoids and steroids; the Darwin Medal to Sir Maurice Yonge, University of Glasgow, for his contributions to evolutionary biology, particularly of the Mollusca; the Hughes Medal to Professor F. J. Dyson, Institute for Advanced Study, Princeton, for his work in theoretical physics, especially on quantum electrodynamics.

A Cooperative Institute for Research in Environmental Sciences has been established on the Boulder campus of the University of Colorado to promote research and leaching in these sciences, and to serve as a centre for multi-disciplinary collaboration between research workers from Boulder and the ${ }^{*}$ rest of the world. A visiting fellowship programme provides funds to enable scientists working in the fields of solid-earth geophysics, oceanography, radio propagation, upper and lower atmosphere physies and solar terrestrial relationships to spend a year with CIRlS. Further 'information can be obtained from the Cooperative Institute for Rescarch in Environmental Sciences, University of Colorado, Boulder, Colorado 80302, USA. 
A new association, entitled the International Confederation on Thermal Analysis, was established at the second international conference on thermal analysis, held in Worcester, Massachusetts, during August 18-23. The association's main functions will be to keep scientists in touch with developments in the field through periodic newsletters, to promote international understanding and cooperation in thermal analysis, and to organize periodic conferences at which problems can be discussed. Further information can be obtained from $\mathrm{Mr} J$. A. Hill, Xerox Corporation, PO Box 1540, Rochester, NY 14603, USA.

The International Potash Institute has organized a third competition for young research workers in which prizes will be awarded for papers on the chemical, biological or physiological role of potassium in the soil, in the vegetable realm or in the animal organism, including the field of human nutrition. Further information can be obtained from the International Potash Institute, 30 Zieglerstrasse, Berne, Switzerland.

Applications are invited for a number of Ciba fellowships to be awarded in February 1969 to enable graduates of universities in the UK and Eire to carry out research-in ehemistry, physics or some other allied scientific subjects-at continental universities during the academic year 1969-70. Applicants may be at present either at university or in industry. Further information can be obtained from the Secretary, The Ciba Fellowship Trust, 96 Piccadilly, London WIV OLN.

Corrigendum. In the introductory paragraph at the top of the article "Survey of Ross's Original Deep Sea Sounding Site" by Robert S. Dietz and Harley J. Knebel (Nature, 220,751; 1968) it was wrongly stated that the first successful sounding of the ocean depths was earried out by Sir John Ross in 1840. It was in fact Sir James Ross who made the first abyssal sounding.

ERratum. In the bibliography of the book Fundamentals of Mycology, the review of which was published in the December 7 issue of Nature $(220,1010 ; 1968)$, we should have stated that a paperback edition of the book was also available at a price of $65 s$.

ERratum. In the communication "Radiation and Matter in an Open Cosmological Model", by A. D. Chernin (Nature, 220, 250; 1968), the last equation in the first column of page 250 should read

$$
A_{m}=\frac{1}{2}\left(\frac{3}{\chi_{0}}\right)^{\frac{1}{2}}\left(\rho_{c}-\rho\right)^{-3 / 2} \rho_{m}, A_{r}=\left(\frac{3}{\chi}\right)^{\frac{1}{2}}\left(\rho_{c}-\rho\right)^{-1} \rho_{r}^{\frac{1}{2}}
$$

ERratum. In the communication "Fracture in Bending, Torsion and Radial Pressure" by C. Gurney (Nature, 220, $61 ; 1968)$, equation (4) should read

$$
E_{1}=\frac{1}{2} X u_{1}=\frac{1}{2} X u_{3}+\frac{1}{2} \int_{0}^{A} \sigma \mathrm{d} A e_{1}
$$

The reference to equation (7) in the fourth paragraph of the second column should be to equation (5), and in the last equation $C$ should be $c$.

Erratum. In the article "Magnetic Models of Pulsars" by V. L. Ginzburg et al. (Nature, 220, 355; 1968) the sentence beginning on the nineteenth line of the third paragraph should begin "If we assume that $\overline{v_{s}} \sim \bar{c}, \ldots$." The penultimate sentence of the same paragraph should read "Besides, we can seo no real mechanism in pulsars for accelerating particles with $\varepsilon \gg M c^{2} \sim 10^{9} \mathrm{eV}$. The second sentence of the sixth paragraph should read "With an asymmetrical orientation of the dipole, the intensity of the subpulses will be different". The second reference should read Maran, S. P., and Cameron, A. G. W., Physics Today, 21, 41 (1968).

\section{International Meetings}

April 1, Tribology, Deeside (Mr R. Harrop, Flintshire College of Technology, Connah's Quay, Deeside, North Wales).

May 4-10, Stereochemistry, Burgenstock, near Lucerne (Professor A. Kjaer, Institute of Organic Chemistry, Technical University of Denmark, Bygning 201, Lyngby, Denmark).

May 5, Organization and Management of Research and Development, London (Meetings Officer, Institute of Physics and the Physical Society, 47 Belgrave Square, London SW1).

May 5-6, Chemistry and Metabolism of Sphingolipids, Michigan (Dr C. C. Sweeley, Department of Biochemistry, Michigan State University, East Lansing, Michigan 48823, USA).

May 6, Grop Protection, Ghent (Professor R. H. Kips, International Symposium on Crop Protection, Rijksfaculteit der Landbouwwetenschappen, Coupure Links 235, Ghent, Belgium).

May 8-9, Organolead and Organozinc Chemistry, Utrecht (Organizing Committee of the Conference on Organolead and Organozinc Chemistry, c/o Jaarbeurs, Utrecht, The Netherlands).

May 12-17, German Engineering Conference, Braunschweig (Verein Deutscher Ingenieure, Postfach 1139, 4 Dusseldorf 1, Germany).

May 19-21, Muscle Diseases, Milan (Dr N. Canal, c/o Clinical delle Malattie Nervose e Mentali, via F. Sforza 35, 20122 Milan, Italy).

May 19-24, Organic Chemistry of Phosphorus, Paris (P. Chabrier, 242 Boul. St Germain, Paris 7, France).

May 22-24, Chemical and Molecular Lasers, St Louis (Dr D. P. Ames, McDonnell Douglas Corporation, OP Box 516, St Louis, Missouri 63166, USA).

May 26-30, Spectroscopy, Madrid (Sr. Secretario, XV Colloquium Spectroscopium Internationale, Serrano 119, Madrid 6, Spain).

May 27-June 1, Medical Continuation Studies, Berlin (Kongressgesellschaft für Artliche Fortbildung, Klingsortstr. 21, Berlin 41, Germany).

May 28-30, German Metallurgical Society Assembly, Berlin (Deutsche Gesellschaft für Metalkunde, Alterburger Str. 402, Koln-Marienburg, Germany).

May 29-June 3, Accident and Traffic Medicine, New York (Dr Milton Helpern, c/o Office of Chief Medical, Examiner, 520 First Avenue, New York, NY 10016, USA).

September 2-6, Cybernetics, London (Dr J. Rose, c/o College of Technology and Design, Blackburn BB2 1 LH, Lancashire, UK).

\section{Sabbatical Itinerants}

In the hope of providing some practical assistance in the good cause of mobility between laboratories Nature is proposing to advertise the needs for housing of families about to take up periods of sabbatical leave. To begin with, no charge will be made for advertisements like this. It is hoped that a period of experiment will show what form these advertisements could most usefully take and whether they are effective.

WANTED : Czechoslovakian doctor requires furnished room or flatlet in Central London from the end of December 1968 for approximately twelve months. Please contact Dr I. A. Macpherson, Imperial Cancer Research Fund, Lincoln's Inn Fields, London WC2 (01-242-9901). 